\title{
A Strategy for Increasing Drug Solubility and Efficacy through Covalent Attachment to Polyvalent DNA-Nanoparticle Conjugates
}

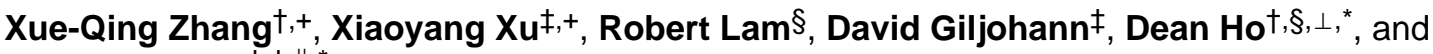 \\ Chad A. Mirkin ${ }^{\ddagger, \dagger}, \|, *$ \\ tDepartment of Biomedical Engineering, Northwestern University, Evanston, Illinois 60208 \\ ‡Department of Chemistry, Northwestern University, Evanston, Illinois 60208 \\ $\S$ Department of Mechanical Engineering, Northwestern University, Evanston, Illinois 60208 \\ "International Institute for Nanotechnology, Northwestern University, Evanston, Illinois 60208 \\ ${ }^{\perp}$ Robert H. Lurie Comprehensive Cancer Center, Northwestern University, Chicago, Illinois 60611
}

\begin{abstract}
Paclitaxel, a potent chemotherapeutic utilized in a variety of cancers, can be limited in its effectiveness due to inherent insolubility in aqueous media and acquired chemoresistance within certain cells. An approach has been developed for increasing Paclitaxel solubility and effectiveness by covalent attachment to gold nanoparticles via DNA linkers. The resulting conjugates are highly soluble in aqueous buffer, exhibiting greater than a 50 fold increase in solubility over the unconjugated drug. DNA linkers are labeled with a fluorophore, which affords a convenient means of visualizing resultant conjugates within cells. Internalized conjugates demonstrate increased activity as compared with free drug across a variety of cell types, including a Paclitaxel-resistant cell line. Attachment to DNA-nanoparticle conjugates may become a general strategy for solubilizing and enhancing a wide variety of therapeutic agents in aqueous media.
\end{abstract}

\section{Keywords}

Paclitaxel; nanoparticle; DNA; gold; chemoresistance; nanomedicine; cancer

One emerging and important class of nanomaterials, polyvalent DNA-functionalized gold nanoparticles (DNA-AuNPs), has been studied and utilized extensively in the fields of biodiagnostics, gene regulation, and nanomedicine. ${ }^{1-6}$ The fundamental properties of these particles, including sharp melting transitions when bound to complementary nucleic acid sequences, catalytic activity, and enhanced target binding have made them extremely useful in the context of biological detection schemes. ${ }^{5}$ These materials also have attractive characteristics and properties that make them excellent candidates for drug delivery applications. ${ }^{4}$ The dense shell of synthetic oligonucleotides allows DNA-AuNPs to be easily dispersed without solvent-induced aggregation in aqueous systems, including buffers with high concentrations of salts and serum-containing cell culture media. In addition, the high

\footnotetext{
*To whom correspondence should be addressed. chadnano@northwestern.edu; d-ho@northwestern.edu. ${ }^{+}$Xue-Qing Zhang and Xiaoyang Xu contributed equally to this work.

Supporting Information Available. Supporting material includes the MTT assay of DNA-AuNPs containing equivalent DNA strand concentrations in MCF7 and MES-SA/Dx5 cells, and the DLS measurements of PTX-DNA@ AuNPs exposed to PBS and EMEM at various temperatures. This material is available free of charge via the internet at http://pubs.acs.org.
} 
surface density of oligonucleotides creates a high local ion concentration, which results in resistance to enzymatic nucleic acid degradation. ${ }^{7}$ DNA-AuNPs are efficiently taken up in high numbers by over 50 different cell lines (including neurons), and primary cells. ${ }^{4}$ This almost universal cell-uptake property has been attributed to the dense loading of the oligonucleotides on the AuNPs, their ability to bind scavenger proteins, and facilitate endocytosis..${ }^{5}$ DNA-AuNPs can be readily modified with a wide variety of compounds using straightforward alkylthiol adsorption on gold chemistry. ${ }^{1,4,5,9-16}$ In particular, recent reports show that the polyvalent attachment of platinum drugs and magnetic resonance imaging (MRI) contrast agents onto DNA-AuNPs results in enhanced cellular uptake and activity..$^{10}$ Although DNA-AuNPs have been extensively studied, they exhibit no apparent cytotoxicity and elicit little innate immune response, ${ }^{6,17}$ alluding to their potential as nontoxic and biocompatible nanomaterials, which may be suitable for clinical use. This property alone potentially overcomes one of the greatest concerns regarding nanomaterials in drug delivery, which to date has limited their wide-spread use in biomedical applications. ${ }^{18-20}$

Attractive due to their enhanced cellular uptake, stability, biocompatibility and versatile surface functionalization, DNA-AuNPs are also a potentially useful system for the delivery of hydrophobic chemotherapeutic agents. ${ }^{4}$ Here we describe the synthesis and characterization of novel Paclitaxel-DNA@AuNP conjugates within the context of in vitro drug delivery.

Paclitaxel, derived from the bark of the pacific yew tree, is one of the most active chemotherapeutic agents used for the treatment of various cancers, especially ovarian, breast, and non-small cell lung cancers for the past decade. ${ }^{21,22}$ As a mitotic inhibitor, Paclitaxel exerts its cytotoxic effect by arresting mitosis through microtubule stabilization and subsequently interfering with the normal breakdown of microtubules during cell division, resulting in cellular apoptosis. ${ }^{22,23}$ Although Paclitaxel has had a significant impact in cancer treatment, the effectiveness of traditional Paclitaxel-based treatment regimens has been limited due to the drug's low aqueous solubility, eventual acquired chemoresistance of cells, and certain side effects. ${ }^{24}$ Its commercial formulation, Taxol ${ }^{\circledR}$ (Bristol-Myers Squibb), is formulated in a high concentration in Cremophor EL, a solvent and excipient material that is necessary to solubilize Paclitaxel but can cause severe side effects, including hypersensitivity reactions, nephrotoxicity, myelosuppression, and peripheral neuropathy. ${ }^{25,26}$ The emerging macroparticle or nanoparticle-based delivery approaches have provided interesting avenues for improving cancer treatments by the controlled delivery and release of chemotherapeutic agents. ${ }^{27-37}$ Among them, several strategies for increasing Paclitaxel solubility and efficacy have been studied, such as the use of emulsification, micellization, liposomes, non-liposomal carriers (microspheres, nanoparticles), cyclodextrins, and local drug delivery devices. ${ }^{25}$ Most of these delivery strategies are focused upon encapsulation methods, ${ }^{31,} 38$ which have been shown to yield particles with high loading and relatively large size (100 nm - micron size). ${ }^{39-41}$ Interestingly, drug-nanoparticle hybrid conjugates have recently garnered significant attention. ${ }^{27,42}$ The smaller structures $(<100 \mathrm{~nm})$ made via this method are more stable, can evade reticuloendothelial system (RES) capture and exhibit the ability to accumulate in a broader range of tumors creating a necessity for nano-sized delivery vehicles. ${ }^{42-45}$ Most nanoparticle-drug conjugates have used oligoethylene glycol (OEG)-based linkers, which do not offer the versatile chemistry afforded by synthetically and mechanically programmable oligonucleotide linkers. As such, facile methods for labeling OEG-drug conjugates for visualization and tracking within cells do not yet exist. Finally, it is important to note that OEG-functionalized particles exhibit a three orders of magnitude lower cellular uptake than antisense DNA-AuNPs. ${ }^{8}$ 
In the study reported herein, paclitaxel molecules are covalently attached to gold nanoparticles via fluorescent antisense oligonucleotide linkers, resulting in a multimodal drug delivery system with simultaneous capabilities in imaging and enhanced therapy. The potency of the resulting conjugates was also tested within a chemoresistant cell line. The data suggest that these conjugates may solve three common problems associated with Paclitaxel as an effective chemotherapeutic agent. First, they enhance the solubility of the drug in aqueous systems such as buffers containing high concentrations of salts and serumcontaining cell culture media. Second, they increase drug efficacy in Paclitaxel-resistant cell lines. Third, they provide a useful way of tracking the movement of the conjugates and delivery of the drug. Indeed, these nanoparticle conjugates form the basis for a new strategy for generally increasing drug solubility and efficacy while simultaneously tracking intracellular uptake.

\section{RESULTS AND DISCUSSION}

Nanoparticle conjugates were prepared by reacting citrate-stabilized gold nanoparticles with propylthiol-capped 20-mer poly-dT oligonucleotides containing a terminal Paclitaxel group (Scheme 1). First, DNA oligomers were synthesized with a terminal amine group for covalent attachment to Paclitaxel. Paclitaxel was modified by reaction with succinic anhydride to create a Paclitaxel carboxilic acid derivative, compound $\mathbf{1}$. The amineterminated DNA and the Paclitaxel carboxilic acid derivative $\mathbf{1}$ were covalently attached to each other via EDC/Sulfo-NHS coupling chemistry to yield compound 2 (Scheme 1). After purification by RP-HPLC, the Paclitaxel-DNA (PTX-DNA), compound 2 was characterized by matrix-assisted laser desorption/ionization mass spectrometry (MALDI-MS), which confirmed its formation (Figure 1). Compound $\mathbf{2}$ was then immobilized on citrate-stabilized AuNPs using literature procedures for making analogous DNA-AuNPs, ${ }^{46}$ ultimately yielding the Paclitaxel-DNA gold nanoparticle conjugates (PTX-DNA@AuNPs) 3. Excess PTX-DNA was removed through repeated centrifugation and resuspension of PTXDNA@AuNPs until no PTX-DNA was detected by MALDI-MS in the supernatant. Fluorescein-labeled PTX-DNA conjugates were synthesized as described in Scheme 1 in order to produce Fluorescein-PTX-DNA@ AuNPs. These fluorophore-labeled structures were used for confocal microscopy imaging experiments and to determine subsequent loading of Paclitaxel onto the nanoparticle conjugates. In order to determine the number of Paclitaxel molecules loaded on each particle, the fluorescent PTX-DNA immobilized on the gold nanoparticle surface was chemically released from the particle by an exchange reaction with dithiothreitol (DTT), and the concentrations of fluorescent PTX-DNA and nanoparticles were measured as described previously for DNA-AuNPs. ${ }^{46}$ The average number of Paclitaxel molecules per nanoparticle was determined to be $59 \pm 8$ by dividing the concentration of fluorescent oligonucleotides by the concentration of nanoparticles.

The aqueous suspension of the PTX-DNA@AuNP conjugates is deep red in color due to the plasmon resonance of the Au nanoparticles at $520 \mathrm{~nm}$ (Figure 2A). The conjugates show no evidence of degradation after 2 months when stored at $4^{\circ} \mathrm{C}$ as an aqueous solution, in contrast with unconjugated Paclitaxel (at a comparable concentration) in PBS, which forms a cloudy suspension consisting of precipitated Paclitaxel (Figure 2A). UV-Vis spectroscopy of the PTX-DNA@AuNPs confirms that the particles remain dispersed in solution after drug conjugation (Figure 2B); aggregation would result in a highly diagnostic red-shift in the surface plasmon resonance for the colloid. ${ }^{3}$ Furthermore, it is interesting to note that the drug-nanoparticle conjugates $\mathbf{3}$ exhibit significantly enhanced solubility in salt-containing buffer. Dynamic light scattering (DLS) analysis and TEM images (Figure 3) indicate that the PTX-DNA@AuNPs are well-dispersed in PBS with a narrow-size distribution, whereas severe aggregation occurs when the same amount of hydrophobic Paclitaxel $(25 \mu \mathrm{M}$ Paclitaxel) is suspended by sonication for several seconds in PBS. When compared with 
unmodified DNA-AuNPs $(29.2 \pm 0.6 \mathrm{~nm})$, PTX-DNA@ AuNPs exhibit a slightly larger average size $(34.7 \pm 1.7 \mathrm{~nm})$ with a polydispersity index (PDI) of 0.2 . As previously reported, free Paclitaxel has a maximum solubility of $0.4 \mu \mathrm{g} / \mathrm{mL}$ in aqueous solution. ${ }^{47} \mathrm{In}$ contrast, the conjugated PTX-DNA@AuNPs were stable in PBS buffer solution at the equivalent Paclitaxel concentration of $21.35 \mu \mathrm{g} / \mathrm{mL}(25 \mu \mathrm{M})$. This represents a greater than 50 fold enhancement in drug solubility when they were bound to the AuNPs compared to free drug. As summarized in table S1, the PTX-DNA@AuNPs are still stable when exposed to Eagle's Minimum Essential Medium (EMEM) at $25^{\circ} \mathrm{C}$ and $37^{\circ} \mathrm{C}$.

Previous reports have shown that the therapeutic effects of drug-loaded nanoparticles often depend on successful internalization and sustained retention by diseased cells. ${ }^{31,} 48$ In this work, we selected DNA-AuNPs as a delivery vehicle for Paclitaxel specifically due to the ability of DNA-AuNPs to enter cells effectively, without the use of transfection reagents. ${ }^{4}$ Indeed, DNA-AuNPs show superior cellular uptake when compared to other types of AuNPs. For example, HeLa cells internalize only a few thousand citrate-coated gold nanoparticles, ${ }^{49}$ compared to over one million DNA-AuNPs under nearly identical conditions. ${ }^{8}$ The cellular uptake of fully oligoethylene glycol-functionalized particles were three orders of magnitude lower than DNA-AuNPs. ${ }^{8}$

The ability of Fluorescein-PTX-DNA@AuNPs to enter cells was investigated by confocal microscopy using gold nanoparticles functionalized with a monolayer of Fluorescein-labeled PTX-DNA molecules (Figure 4). Confocal fluorescence images show the successful internalization of the fluorophore-labeled conjugates in MCF7 human breast adenocarcinoma cells and MES-SA/Dx5 human uterine sarcoma cells after 6 hours of incubation. Within both cell lines, the Fluorescein-PTX-DNA@ AuNPs are observed in the cytoplasm, indicating the efficient translocation of the Paclitaxel-gold nanoparticle conjugates.

In order to test the activity of the nanoparticle conjugate, a terminal deoxynucleotidyl transferase dUTP nick end labeling (TUNEL) assay ${ }^{50}$ was performed to measure DNA fragmentation and apoptosis induced by Paclitaxel. MCF7 or MES-SA/Dx5 cells were incubated with drug-free DNA-AuNPs, free Paclitaxel, compound 1, and PTX-

DNA@AuNPs 3, respectively, at varying concentrations for 48 hours (Figure 5). Unlike MCF7 cells, MES-SA/Dx5 cells express high levels of mdr-1 mRNA and P-glycoprotein and exhibit a marked cross resistance to a number of chemotherapeutic agents, including Paclitaxel. ${ }^{51-53}$ Untreated cells and drug-free DNA-AuNPs were used as negative controls. When treated with $100 \mathrm{nM}$ of free Paclitaxel or compound 1 (positive controls), MES-SA/ Dx5 cells (Figure 5B) exhibit a lower fraction of TUNEL-positive signals in comparison with MCF7 cells (Figure 5A), demonstrating the MES-SA/Dx5 cells' inherent resistance towards Paclitaxel. It is worthwhile to note that the intense signal of TUNEL-positive cells and diminished population of the conjugates 3 treated samples relative to positive controls are clearly observed in both MCF7 cells and MES-SA/Dx5. The TUNEL staining images indicate that Paclitaxel remains active upon conjugation, strongly suggesting the resulting gold nanoparticle conjugates $\mathbf{3}$ have the potential to circumvent Paclitaxel resistance.

In order to evaluate the efficacy of PTX-DNA@AuNPs 3, we investigated their ability to kill cancer cells of various origins. Figure 6 shows the in vitro viability of MCF7, MES-SA/ Dx5 and SKOV-3 ovarian cancer cells cultured with Paclitaxel, compound 1 and PTXDNA@AuNP conjugates 3 as a function of Paclitaxel concentration (0.064 to $1000 \mathrm{nM}$; note that for the particles, the absolute Paclitaxel concentration was equalized based upon the number of molecules on the surface of the particle). MTT assays of DNA-AuNPs containing equivalent DNA strand concentrations were also conducted using MCF7 and MES-SA/Dx5 cells as negative controls (Figure S1). DNA-AuNPs without drug generate little cytotoxic 
profile within MCF7 and MES-SA/Dx5 cells even after 48 hours of incubation. More than 75-90\% of cells are viable at $48 \mathrm{~h}$ when cultured with DNA-AuNPs at DNA concentrations at or above $1 \mu \mathrm{M}$. However, as shown in Figure 6, after $12 \mathrm{~h}$ or $48 \mathrm{~h}$ treatment with different concentrations of PTX-DNA@AuNPs 3, cytotoxicity was observed in all three cell lines as compared with Paclitaxel and compound 1 alone. In particular, MES-SA/Dx 5 cell viability after 2 days incubation at $200 \mathrm{nM}$ drug concentration was decreased from $84.3 \%$ for compound 1 to $76.0 \%$ for Paclitaxel alone and to 35.4\% for the PTX-DNA@ AuNP 3 formulation. Both Paclitaxel and compound 1 did not display significant therapeutic activity under the same conditions in Paclitaxel-resistant MES-SA/Dx5 cells, while the activity of Paclitaxel was considerably enhanced when tethered to DNA-AuNPs. Similarly, in MCF7 and SKOV-3 cells, PTX-DNA@ AuNPs 3 reflect efficacy greater than that of Paclitaxel and compound 1 after 12 and $48 \mathrm{~h}$ incubation. The improved cytotoxicity as a result of PTXDNA@AuNP 3 addition could be due to the enhanced cellular uptake of the conjugates in comparison with free drug. In addition, the results suggest that nanoparticle-mediated drug delivery can potentially overcome the cellular cross resistance of a number of chemotherapeutic agents in vitro. Multiple drug resistance (MDR) often occurs when transporter proteins that expel drugs from cells are over expressed on the surface of cancer cells. ${ }^{51,54-56}$ Nanoparticles can reduce the chemoresistance that characterizes many anticancer drugs, including Paclitaxel, by facilitating the internalization of the drug, ${ }^{31,57}$ and reducing its efflux from cells mediated by P-glycoprotein (P-gp). ${ }^{58-63}$

The effect in MCF7, SKOV-3 and MES-SA/Dx5 cells after incubation at various drug concentrations can be determined by comparing $\mathrm{IC}_{50}$ values (Table 1 ). The data clearly demonstrate the advantage of utilizing the DNA-nanoparticle conjugates. For instance, the $\mathrm{IC}_{50}$ value for MCF7 cells decreases from above $1 \mu \mathrm{M}$ and $193 \mathrm{nM}$ for free Paclitaxel to $119.4 \mathrm{nM}$ and $52.6 \mathrm{nM}$ for PTX-DNA@ @uNPs 3 after 12 and $48 \mathrm{~h}$ incubation, respectively. In resistant MES-SA/Dx 5 cells, both Paclitaxel and compound 1 have IC50 values above 1 $\mu \mathrm{M}$, whereas PTX-DNA@AuNPs 3 exhibit IC50 values of $118 \mathrm{nM}$ and $104.5 \mathrm{nM}$ after incubation for 12 and $48 \mathrm{~h}$, respectively. A similar trend is observed in SKOV-3 cells. After $48 \mathrm{~h}$ incubation, PTX-DNA@AuNPs have an IC50 value of $17.5 \mathrm{nM}$, lower than that of Paclitaxel $(28.9 \mathrm{nM})$ and compound $\mathbf{1}(188.0 \mathrm{nM})$, attesting to the enhanced activity across different cancer cell lines of the Paclitaxel compound upon conjugation to a gold nanoparticle via DNA linkers.

\section{CONCLUSION}

In conclusion, we have developed an effective chemical strategy for delivering hydrophobic Paclitaxel while simultaneously overcoming drug efflux in human cancer cells. Covalently attaching hydrophobic Paclitaxel onto gold nanoparticles via a DNA spacer resulted in significantly enhanced hydrophilicity and stability as compared to free Paclitaxel alone. The visualization of fluorescein-labeled PTX-DNA@ AuNPs within human breast adenocarcinoma cells and uterine sarcoma cells by confocal fluorescence microscopy demonstrates the cellular internalization, delivery and distribution of Paclitaxel. Furthermore, the cell-killing activity of Paclitaxel was enhanced in vitro against several cancer cell lines when attached onto DNA-AuNPs. In TUNEL and MTT assays across several concentrations and cell lines, PTX-DNA@AuNPs 3 were more effective than free drug in inducing apoptosis, most notably within Paclitaxel resistant MES-SA/Dx5 cells. While continued work investigating the mechanism of enhanced efficacy, biodistribution, pharmacokinetic and pharmacodynamic of PTX-DNA@AuNPs in vivo are being explored, the approach presented here could be easily extended to include other biologically relevant components, such as peptides ${ }^{9}$, small interfering RNA (siRNA) ${ }^{11}$, Gadolinium complexes ${ }^{10}$, antibodies ${ }^{64}$ and aptamers ${ }^{65}$, allowing for additional modalities to be introduced by utilizing 
functional groups presented on a DNA linker. Indeed, DNA-AuNPs are becoming a powerful new platform for combinational therapy, bioimaging, and biodiagnostics.

\section{MATERIALS AND METHODS}

1-Ethyl-3-[3-dimethylaminopropyl]carbodiimide hydrochloride (EDC) and $\mathrm{N}$ hydroxysulfosuccinimide (Sulfo-NHS) were purchased from Thermo Fisher Scientific (Rockford, IL, USA). All the other materials and solvents were purchased from SigmaAldrich Chemical Co. (St. Louis, MO, USA) and used without further purification unless noted. Citrate-stabilized AuNPs ( $13 \pm 1.0 \mathrm{~nm}$ diameter) were prepared by the Frens method, ${ }^{66}$ resulting in $\sim 10 \mathrm{nM}$ solutions. Compound 1 was synthesized by succinic anhydride according to the literature, ${ }^{67}$ adding a carboxyl acid group on the molecule at the C-2'-OH position as shown in Scheme 1. The compound 1 was characterized by ESI-MS (Thermo Finnegan LCQ, Integrated Molecular Structure Education and Research Center, Northwestern University). M/Z: Calcd. $=953.98 ;$ Found $=953.92$.

\section{Synthesis of Paclitaxel-Oligonucleotide Conjugate 2}

Oligonucleotides were synthesized on an Expedite 8909 Nucleotide Synthesis System (ABI) using standard solid-phase phosphoramidite methodology. Bases and reagents were purchased from Glen Research (Sterling, VA, USA). The oligonucleotide used to functionalize the AuNPs was amine functionalized strand 5'NH2-T20-hexyldisulfide 3'. The oligonucleotide was purified by reverse-phase high performance liquid chromatography (RP-HPLC) and characterized by MALDI-MS (Bruker Apex III, Integrated Molecular Structure Education and Research Center, Northwestern University). The concentration of oligonucleotide was determined by monitoring the absorbance at $260 \mathrm{~nm}$ with a UV-Vis spectrophotometer. The strand was then reacted with 1 via EDC/Sulfo-NHS chemistry to prepare the PTX-DNA conjugate. In a typical reaction, $0.5 \mathrm{~mL}$ of compound 1 in acetonitrile solution was added to $1 \mathrm{~mL}$ of 10 times molar excess of Sulfo-NHS and EDC solution in HEPES buffer $(0.1 \mathrm{M}, \mathrm{pH}=7)$. The resultant mixture was allowed to react at room temperature for $15 \mathrm{~min}$. 0.5 molar equivalents (relative to 1 ) of oligonucleotide strand 5'NH2-T20-hexyldisulfide 3' was added to the solution. The reaction mixture was shaken gently for 3 days at room temperature. The PTX-DNA conjugate was purified by RP-HPLC and characterized by MALDI-MS (Figure S1). For quantification of paclitaxel loaded on the nanoparticle and cellular imaging, an additional Fluorescein/amine-modified strand (5' NH2-T9-(Fluorescein-dT Phosphoramidite)-T10-hexyldisulfide 3') was synthesized and reacted in a similar fashion to obtain a Fluorescein-labeled PTX-DNA conjugate 2.

\section{Preparation of PTX-DNA@AuNPs and Fluorescein-PTX-DNA@AuNPs 3}

The oligonucleotide AuNP conjugates were synthesized as described previously. ${ }^{46}$ Briefly, disulfide functionalized oligonucleotides were freshly cleaved by dithiothreitol (DTT) for 1 $\mathrm{h}$ at room temperature prior to use. The cleaved oligonucleotides were purified using NAP-10 columns (GE Healthcare). Freshly cleaved oligonucleotides were then added to gold nanoparticles $(1 \mathrm{OD} / 1 \mathrm{~mL})$. After a $16 \mathrm{~h}$ incubation, the concentrations of PBS and sodium dodecyl sulfate (SDS) were brought to $0.01 \mathrm{M}$ and $0.01 \%$, respectively. The oligonucleotide/gold nanoparticle solution was allowed to incubate at room temperature for 20 min. $\mathrm{NaCl}$ was added using $2 \mathrm{M} \mathrm{NaCl}$ with a repeated salting increments of $0.02 \mathrm{M} \mathrm{NaCl}$ every $5 \mathrm{~h}$ until a concentration of $0.1 \mathrm{M} \mathrm{NaCl}$ was reached while maintaining an SDS concentration of $0.01 \%$. The salting process was followed by an overnight incubation at room temperature. The final conjugates were stored in buffer with excess oligonucleotides at $4{ }^{\circ} \mathrm{C}$. Before use, the PTX-DNA@ @uNP or Fluorescein-PTX-DNA@ AuNP 3 were spun down and washed until there were no strands detected by MALDI-MS in the supernatant. 


\section{Quantification of Alkanethiol Oligonucleotides Loaded on Gold Nanoparticles}

The number of oligonucleotides loaded on each particle was determined by measuring the concentration of nanoparticles and the concentration of fluorescent DNA in each sample as previously reported. ${ }^{46}$ The concentration of gold nanoparticles in each aliquot was determined by performing UV-vis spectroscopy measurements. These absorbance values were then related to the nanoparticle concentration via Beer's law $(\mathrm{A}=\varepsilon b c)$. The wavelength of the absorbance maximums $(\lambda)$ and extinction coefficients $(\varepsilon)$ used for $13 \mathrm{~nm}$ gold nanoparticles are as follows: $\lambda=520 \mathrm{~nm}, \varepsilon=2.7 \times 10^{8} \mathrm{M}^{-1} \mathrm{~cm}^{-1}$.

In order to determine the concentration of fluorescent oligonucleotides in each aliquot, DNA was chemically displaced from the nanoparticle surface using 1.0 M DTT in $0.18 \mathrm{M}$ PBS, $\mathrm{pH}$ 8.0. The oligonucleotides were cleaved from the nanoparticle surface into solution during an overnight incubation, and the gold precipitate subsequently removed by centrifugation. To determine oligonucleotide concentration, $100 \mu \mathrm{L}$ of supernatant was placed in a 96-well plate and the fluorescence was compared to a standard curve prepared with the same 1.0 M DTT buffer solution. During fluorescence measurements, the fluorophore was excited at $490 \mathrm{~nm}$ and the emission was collected at $520 \mathrm{~nm}$. The number of oligonucleotides per particle for each aliquot was calculated by dividing the concentration of fluorescent oligonucleotides by the concentration of nanoparticles. The experiment was repeated three times using fresh samples to obtain reliable error bars.

\section{Dynamic Light Scattering (DLS) and Transmission Electron Microscopy (TEM)}

PTX-DNA@AuNPs or DNA-AuNPs were resuspended in 200 uL PBS buffer with oligonucleotide strands of an equivalent concentration of $25 \mu \mathrm{M}$. Hydrodynamic size measurements were conducted using the Zetasizer Nano ZS (Malvern, Worcestershire, U.K.). The size measurements were performed at $25^{\circ} \mathrm{C}$ at a $173^{\circ}$ scattering angle in disposable micro cuvettes (minimum volume $40 \mu \mathrm{L}$, Malvern, Worcestershire, U.K.). The mean hydrodynamic diameter was determined by cumulative analysis. Transmission Electron Microscopy (TEM) was performed using a 200 kV Hitachi H-8100 TEM (EPIC, Northwestern University). Diluted PTX-DNA@AuNPs in deionized water were pipetted onto a commercial carbon TEM grid (Ted Pella Inc., Redding, CA). Upon air drying for $2 \mathrm{~h}$, samples were then observed within a Hitachi H-8100 TEM.

\section{General Cell Culture}

MCF7, SKOV-3 and MES-SA/Dx5 cells were purchased from American Type Culture Collection (ATCC, Manassas, VA, USA). Media, Dulbecco's phosphate buffered saline (DPBS), and $0.25 \%$ trypsin/EDTA were purchased from Invitrogen (Carlsbad, CA, USA). MCF7 cells were cultured in Eagle's Minimum Essential Medium (EMEM) supplemented with $10 \%$ fetal bovine serum (FBS) and $0.01 \mathrm{mg} / \mathrm{ml}$ bovine insulin. SKOV-3 and MES-SA/ Dx5 cells were cultured using McCoy's 5A modified media supplemented with 10\% FBS. All experiments were performed in the aforementioned cell-specific media in a $5 \% \mathrm{CO}_{2}$ incubator at $37^{\circ} \mathrm{C}$.

\section{Fluorescence Imaging}

MCF7 and MES-SA/Dx5 cells were grown on Lab-Tek® II Chamber \#1.5 German Coverglass System (Thermo Scientific - Nunc International, Naperville, IL, USA) for $24 \mathrm{~h}$ prior to imaging. $0.42 \mathrm{nM}$ Fluorescein-PTX-DNA@ AuNPs 3 (corresponding to fluorescein labeled strands with a concentration of $25 \mathrm{nM}$ ) were then added directly to the cell culture media. After $6 \mathrm{~h}$ treatment, cells were rinsed with PBS and fresh media added. Live cells were stained with Cellular Lights ${ }^{\mathrm{TM}}$ Actin-RFP (Invitrogen) and DRAQ5 (Biostatus Ltd.) for cytoplasmic actin staining and nuclear staining, respectively, according to manufacturer's 
instructions. Images were acquired on a Zeiss LSM 510 inverted microscope (computer controlled using Zeiss Zen software). An Appochromat water immersion objective (40X, NA 1.2) was used for all measurements.

TUNEL Assay

MCF7 and MES-SA/Dx5 cells were seeded on $0.17 \mathrm{~mm}$ thick coverslips in 12-well plates at a density of $2 \times 10^{5}$ cells/well for $24 \mathrm{~h}$ prior to fluorescent TUNEL assay. Cells were treated with nothing, DNA-AuNPs at a DNA strand concentration of $100 \mathrm{nM}$ (negative controls), $100 \mathrm{nM}$ of free paclitaxel and compound 1 (positive controls), PTX-DNA@AuNPs at the equivalent paclitaxel concentrations of $50 \mathrm{nM}$ and $100 \mathrm{nM}$ (samples), respectively, for $48 \mathrm{~h}$. Live cells were rinsed and stained in accordance with instructions and materials for adherent cultured cells provided by Chemicon International ApopTag Plus Fluorescein In situ Apoptosis Detection Kit S7111 (Temecula, CA). ApopTag utilizes the terminal deoxynucleotidyl transferase (TdT) enzyme to amplify the fluorescein-conjugated antidigoxigenin antibody, a secondary antibody towards digoxigenin-labeled nucleotide-labeled 30-OH termini on DNA fragments. Images were acquired on a Zeiss LSM 510 inverted microscope (computer controlled using Zeiss Zen software).

\section{MTT Assay}

The cytotoxicity profiles of PTX-DNA@AuNP conjugates, paclitaxel and compound 1 in MCF7, MES-SA/Dx5 and SKOV-3 cells were investigated using a 3-(4,5-dimethylthiazol-2yl-)-2,5-diphenyltetrazolium bromide (MTT) assay following the manufacturer's protocol. Briefly, cells were seeded on 96-well plates for $24 \mathrm{~h}$ before the assay at a density of $1.5 \times$ $10^{4}$ cells/well. Following $24 \mathrm{~h}$ growth, media was replaced with $200 \mu \mathrm{L}$ of corresponding sample solutions, which were freshly prepared at varying concentrations in complete cell culture media. Cells in media containing 10\% FBS with nothing added were used as controls. After $12 \mathrm{~h}$ or $48 \mathrm{~h}$ treatment, cells were rinsed and cultured with fresh medium containing $0.5 \mathrm{mg} / \mathrm{mL}$ of MTT for an additional $3 \mathrm{~h}$. Following careful aspiration of MTT solution and media after MTT incubation, $200 \mu \mathrm{L}$ of MTT solubilization solution was added to each well and thoroughly mixed. The optical density at $570 \mathrm{~nm}$ was measured using a Safire microplate reader (Tecan Systems, Inc., San Jose, CA). Background absorbance at $690 \mathrm{~nm}$ was subtracted. Values were expressed as a percentage of the control (incubated with media alone). All conditions were done in sextuplicate in two independent experiments for each cell line.

\section{Supplementary Material}

Refer to Web version on PubMed Central for supplementary material.

\section{Acknowledgments}

C.A.Mirkin acknowledges this work was supported by the Nanoscale Science and Engineering Initiative of the National Science Foundation under NSF Award Number EEC- 0647560 and further supported by Award Number U54CA151880 from the National Cancer Institute. D. Ho is grateful for support from the National Science Foundation (CAREER Award: CMMI-0846323), National Science Foundation Mechanics of Materials program grant (CMMI-0856492), V Foundation for Cancer Research V Scholars Award, National Science Foundation Center for Scalable and Integrated NanoManufacturing (SINAM) grant (DMI-0327077), Wallace H. Coulter Foundation Early Career Award in Translational Research, National Science Foundation National Center for Learning \& Teaching in Nanoscale Science and Engineering (NCLT), and National Institutes of Health grant (U54 A1065359). We thank the Northwestern University Integrated Molecular Structure Education and Research Center (IMSERC); a description of the facility and full funding disclosure can be found at http://pyrite.chem.northwestern.edu/analyticalserviceslab/asl.htm. 


\section{REFERENCES}

1. Dhar S, Daniel WL, Giljohann DA, Mirkin CA, Lippard SJ. Polyvalent Oligonucleotide Gold Nanoparticle Conjugates As Delivery Vehicles for Platinum(IV) Warheads. J. Am. Chem. Soc. 2009; 131:14652-14653. [PubMed: 19778015]

2. Mirkin CA, Letsinger RL, Mucic RC, Storhoff JJ. A DNA-Based Method for Rationally Assembling Nanoparticles into Macroscopic Materials. Nature. 1996; 382:607-609. [PubMed: 8757129]

3. Elghanian R, Storhoff JJ, Mucic RC, Letsinger RL, Mirkin CA. Selective Colorimetric Detection of Polynucleotides Based on the Distance-Dependent Optical Properties of Gold Nanoparticles. Science. 1997; 277:1078-1081. [PubMed: 9262471]

4. Giljohann DA, Seferos DS, Daniel WL, Massich MD, Patel PC, Mirkin CA. Gold Nanoparticles for Biology and Medicine. Angew. Chem. Int. Ed. 2010; 49:3280-3294.

5. Rosi NL, Mirkin CA. Nanostructures in Biodiagnostics. Chem. Rev. 2005; 105:1547-1562. [PubMed: 15826019]

6. Rosi NL, Giljohann DA, Thaxton CS, Lytton-Jean AK, Han MS, Mirkin CA. OligonucleotideModified Gold Nanoparticles for Intracellular Gene Regulation. Science. 2006; 312:1027-1030. [PubMed: 16709779]

7. Seferos DS, Prigodich AE, Giljohann DA, Patel PC, Mirkin CA. Polyvalent DNA Nanoparticle Conjugates Stabilize Nucleic Acids. Nano Lett. 2009; 9:308-311. [PubMed: 19099465]

8. Giljohann DA, Seferos DS, Patel PC, Millstone JE, Rosi NL, Mirkin CA. Oligonucleotide Loading Determines Cellular Uptake of DNA-Modified Gold Nanoparticles. Nano Lett. 2007; 7:3818-3821. [PubMed: 17997588]

9. Patel PC, Giljohann DA, Seferos DS, Mirkin CA. Peptide Antisense Nanoparticles. Proc. Natl. Acad. Sci. U.S.A. 2008; 105:17222-17226. [PubMed: 19004812]

10. Song Y, Xu XY, MacRenaris KW, Zhang XQ, Mirkin CA, Meade TJ. Multimodal GadoliniumEnriched DNA-Gold Nanoparticle Conjugates for Cellular Imaging. Angew. Chem. Int. Ed. 2009; 48:9143-9147.

11. Giljohann DA, Seferos DS, Prigodich AE, Patel PC, Mirkin CA. Gene Regulation with Polyvalent siRNA-Nanoparticle Conjugates. J. Am. Chem. Soc. 2009; 131:2072-2073. [PubMed: 19170493]

12. Xu X, Daniel WL, Wei W, Mirkin CA. Colorimetric $\mathrm{Cu}(2+)$ Detection Using DNA-Modified Gold-Nanoparticle Aggregates As Probes and Click Chemistry. Small. 2010; 6:623-626. [PubMed: 20108231]

13. Xu X, Han MS, Mirkin CA. A Gold-Nanoparticle-Based Real-Time Colorimetric Screening Method for Endonuclease Activity and Inhibition. Angew. Chem. Int. Ed. 2007; 46:3468-3470.

14. Katz E, Willner I. Integrated Nanoparticle-Biomolecule Hybrid Systems: Synthesis, Properties, and Applications. Angew. Chem. Int. Ed. 2004; 43:6042-6108.

15. Lee JS, Han MS, Mirkin CA. Colorimetric Detection of Mercuric Ion $\left(\mathrm{Hg}^{2+}\right)$ in Aqueous Media Using DNA-Functionalized Gold Nanoparticles. Angew. Chem. Int. Ed. 2007; 46:4093-4096.

16. Lee JH, Wang Z, Liu J, Lu Y. Highly Sensitive and Selective Colorimetric Sensors for Uranyl $\left(\mathrm{UO}_{2}{ }^{2+}\right)$ : Development and Comparison of Labeled and Label-Free DNAzyme-Gold Nanoparticle Systems. J. Am. Chem. Soc. 2008; 130:14217-14226. [PubMed: 18837498]

17. Massich MD, Giljohann DA, Seferos DS, Ludlow LE, Horvath CM, Mirkin CA. Regulating Immune Response Using Polyvalent Nucleic Acid-Gold Nanoparticle Conjugates. Mol. Pharm. 2009; 6:1934-1940. [PubMed: 19810673]

18. Service RF. Nanotoxicology: Nanotechnology Grows Up. Science. 2004; 304:1732-1734. [PubMed: 15205504]

19. Nel A, Xia T, Madler L, Li N. Toxic Potential of Materials at the Nanolevel. Science. 2006; 311:622-627. [PubMed: 16456071]

20. Jahnen-Dechent W, Simon U. Function Follows Form: Shape Complementarity and Nanoparticle Toxicity. Nanomedicine. 2008; 3:601-603. [PubMed: 18817462]

21. Dubois J. Recent Progress in the Development of Docetaxel and Paclitaxel Analogues. Expert Opin. Ther. Pat. 2006; 16:1481-1496. 
22. Marupudi NI, Han JE, Li KW, Renard VM, Tyler BM, Brem H. Paclitaxel: a Review of Adverse Toxicities and Novel Delivery Strategies. Expert Opinion on Drug Safety. 2007; 6:609-621. [PubMed: 17877447]

23. Schiff PB, Horwitz SB. Taxol Stabilizes Microtubules in Mouse Fibroblast Cells. Proc. Natl. Acad. Sci. U.S.A. 1980; 77:1561-1565. [PubMed: 6103535]

24. Panchagnula R. Pharmaceutical Aspects of Paclitaxel. Int. J. Pharm. 1998; 172:1-15.

25. Singla AK, Garg A, Aggarwal D. Paclitaxel and its Formulations. Int. J. Pharm. 2002; 235:179192. [PubMed: 11879753]

26. Chao TC, Chu ZT, Tseng LM, Chiou TJ, Hsieh RK, Wang WS, Yen CC, Yang MH, Hsiao LT, Liu $\mathrm{JH}$, et al. Paclitaxel in a Novel Formulation Containing Less Cremophor EL As First-Line Therapy for Advanced Breast Cancer: a Phase II Trial. Invest. New Drugs. 2005; 23:171-177. [PubMed: 15744594]

27. Hwu JR, Lin YS, Josephrajan T, Hsu MH, Cheng FY, Yeh CS, Su WC, Shieh DB. Targeted Paclitaxel by Conjugation to Iron Oxide and Gold Nanoparticles. J. Am. Chem. Soc. 2009; 131:66-68. [PubMed: 19072111]

28. Du L, Liao S, Khatib HA, Stoddart JF, Zink JI. Controlled-Access Hollow Mechanized Silica Nanocontainers. J. Am. Chem. Soc. 2009; 131:15136-15142. [PubMed: 19799420]

29. Liu Z, Chen K, Davis C, Sherlock S, Cao Q, Chen X, Dai H. Drug Delivery with Carbon Nanotubes for in Vivo Cancer Treatment. Cancer Res. 2008; 68:6652-6660. [PubMed: 18701489]

30. Ruan G, Agrawal A, Marcus AI, Nie S. Imaging and Tracking of Tat Peptide-Conjugated Quantum Dots in Living Cells: New Insights into Nanoparticle Uptake, Intracellular Transport, and Vesicle Shedding. J. Am. Chem. Soc. 2007; 129:14759-14766. [PubMed: 17983227]

31. Zhang Y, Tang L, Sun L, Bao J, Song C, Huang L, Liu K, Tian Y, Tian G, Li Z, et al. A Novel Paclitaxel-Loaded Poly(Epsilon-Caprolactone)/Poloxamer 188 Blend Nanoparticle Overcoming Multidrug Resistance for Cancer Treatment. Acta Biomater. 2010; 6:2045-2052. [PubMed: 19969111]

32. Dhar S, Gu FX, Langer R, Farokhzad OC, Lippard SJ. Targeted Delivery of Cisplatin to Prostate Cancer Cells by Aptamer Functionalized Pt(IV) Prodrug-PLGA-PEG Nanoparticles. Proc. Natl. Acad. Sci. U.S.A. 2008; 105:17356-17361. [PubMed: 18978032]

33. Petros RA, Ropp PA, DeSimone JM. Reductively Labile PRINT Particles for the Delivery of Doxorubicin to Hela Cells. J. Am. Chem. Soc. 2008; 130:5008-5009. [PubMed: 18355010]

34. Davis ME, Zuckerman JE, Choi CH, Seligson D, Tolcher A, Alabi CA, Yen Y, Heidel JD, Ribas A. Evidence of RNAi in Humans from Systemically Administered siRNA via Targeted Nanoparticles. Nature. 2010; 464:1067-1070. [PubMed: 20305636]

35. Gu Z, Yan M, Hu BL, Joo KI, Biswas A, Huang Y, Lu YF, Wang P, Tang Y. Protein Nanocapsule Weaved with Enzymatically Degradable Polymeric Network. Nano Lett. 2009; 9:4533-4538. [PubMed: 19995089]

36. Perrault SD, Walkey C, Jennings T, Fischer HC, Chan WCW. Mediating Tumor Targeting Efficiency of Nanoparticles through Design. Nano Lett. 2009; 9:1909-1915. [PubMed: 19344179]

37. Chow EK, Zhang XQ, Chen M, Lam R, Robinson E, Huang H, Schaffer D, Osawa E, Goga A, Ho D. Nanodiamond Therapeutic Delivery Agents Mediate Enhanced Chemoresistant Tumor Treatment. Sci. Transl. Med. 2011; 3 73ra21.

38. Griset AP, Walpole J, Liu R, Gaffey A, Colson YL, Grinstaff MW. Expansile Nanoparticles: Synthesis, Characterization, and in Vivo Efficacy of an Acid-Responsive Polymeric Drug Delivery System. J. Am. Chem. Soc. 2009; 131:2469-2471. [PubMed: 19182897]

39. Farokhzad OC, Cheng JJ, Teply BA, Sherifi I, Jon S, Kantoff PW, Richie JP, Langer R. Targeted Nanoparticle-Aptamer Bioconjugates for Cancer Chemotherapy in Vivo. Proc. Natl. Acad. Sci. U.S.A. 2006; 103:6315-6320. [PubMed: 16606824]

40. Torchilin VP, Lukyanov AN, Gao ZG, Papahadjopoulos-Sternberg B. Immunomicelles: Targeted Pharmaceutical Carriers for Poorly Soluble Drugs. Proc. Natl. Acad. Sci. U.S.A. 2003; 100:60396044. [PubMed: 12716967]

41. Gref R, Minamitake Y, Peracchia MT, Trubetskoy V, Torchilin V, Langer R. Biodegradable LongCirculating Polymeric Nanospheres. Science. 1994; 263:1600-1603. [PubMed: 8128245] 
42. Gibson JD, Khanal BP, Zubarev ER. Paclitaxel-Functionalized Gold Nanoparticles. J. Am. Chem. Soc. 2007; 129:11653-11661. [PubMed: 17718495]

43. Chithrani BD, Chan WCW. Elucidating the Mechanism of Cellular Uptake and Removal of Protein-Coated Gold Nanoparticles of Different Sizes and Shapes. Nano Lett. 2007; 7:1542-1550. [PubMed: 17465586]

44. Kam NWS, Liu ZA, Dai HJ. Carbon Nanotubes As Intracellular Transporters for Proteins and DNA: an Investigation of the Uptake Mechanism and Pathway. Angew. Chem. Int. Ed. 2006; 45:577-581.

45. Hobbs SK, Monsky WL, Yuan F, Roberts WG, Griffith L, Torchilin VP, Jain RK. Regulation of Transport Pathways in Tumor Vessels: Role of Tumor Type and Microenvironment. Proc. Natl. Acad. Sci. U.S.A. 1998; 95:4607-4612. [PubMed: 9539785]

46. Hurst SJ, Lytton-Jean AK, Mirkin CA. Maximizing DNA Loading on a Range of Gold Nanoparticle Sizes. Anal. Chem. 2006; 78:8313-8318. [PubMed: 17165821]

47. Skwarczynski M, Hayashi Y, Kiso Y. Paclitaxel Prodrugs: Toward Smarter Delivery of Anticancer Agents. J. Med. Chem. 2006; 49:7253-7269. [PubMed: 17149855]

48. Jin C, Bai L, Wu H, Tian F, Guo G. Radiosensitization of Paclitaxel, Etanidazole and Paclitaxel +Etanidazole Nanoparticles on Hypoxic Human Tumor Cells in Vitro. Biomaterials. 2007; 28:3724-3730. [PubMed: 17509678]

49. Chithrani BD, Ghazani AA, Chan WC. Determining the Size and Shape Dependence of Gold Nanoparticle Uptake into Mammalian Cells. Nano Lett. 2006; 6:662-668. [PubMed: 16608261]

50. Gavrieli Y, Sherman Y, Bensasson SA. Identification of Programmed Cell-Death in Situ via Specific Labeling of Nuclear-DNA Fragmentation. J. Cell Biol. 1992; 119:493-501. [PubMed: 1400587]

51. Angelini A, Iezzi M, Di Febbo C, Di Ilio C, Cuccurullo F, Porreca E. Reversal of P-GlycoproteinMediated Multidrug Resistance in Human Sarcoma MESSA/Dx- 5 Cells by Nonsteroidal AntiInflammatory Drugs. Oncol. Rep. 2008; 20:731-735. [PubMed: 18813811]

52. Chen GK, Duran GE, Mangili A, Beketic-Oreskovic L, Sikic BI. MDR 1 Activation is the Predominant Resistance Mechanism Selected by Vinblastine in MES-SA Cells. Br. J. Cancer. 2000; 83:892-898. [PubMed: 10970691]

53. Chu ES, Yow CM, Shi M, Ho RJ. Effects of Photoactivated 5-Aminolevulinic Acid Hexyl Ester on MDR1 Over-Expressing Human Uterine Sarcoma Cells. Toxicol Lett. 2008; 181:7-12. [PubMed: 18625294]

54. Ferrari M. Cancer Nanotechnology: Opportunities and Challenges. Nat. Rev. Cancer. 2005; 5:161171. [PubMed: 15738981]

55. Gottesman MM, Fojo T, Bates SE. Multidrug Resistance in Cancer: Role of ATP-Dependent Transporters. Nat. Rev. Cancer. 2002; 2:48-58. [PubMed: 11902585]

56. Peer D, Margalit R. Fluoxetine and Reversal of Multidrug Resistance. Cancer Lett. 2006; 237:180187. [PubMed: 16014320]

57. Buxton DB. Nanomedicine for the Management of Lung and Blood Diseases. Nanomedicine. 2009; 4:331-339. [PubMed: 19331540]

58. Brigger I, Dubernet C, Couvreur P. Nanoparticles in Cancer Therapy and Diagnosis. Adv. Drug. Deliv. Rev. 2002; 54:631-651. [PubMed: 12204596]

59. Devalapally H, Duan Z, Seiden MV, Amiji MM. Paclitaxel and Ceramide Co-Administration in Biodegradable Polymeric Nanoparticulate Delivery System to Overcome Drug Resistance in Ovarian Cancer. Int. J. Cancer. 2007; 121:1830-1838. [PubMed: 17557285]

60. Onyuksel H, Jeon E, Rubinstein I. Nanomicellar Paclitaxel Increases Cytotoxicity of Multidrug Resistant Breast Cancer Cells. Cancer Lett. 2009; 274:327-330. [PubMed: 19022562]

61. Tang Y, Lei T, Manchanda R, Nagesetti A, Fernandez-Fernandez A, Srinivasan S, McGoron AJ. Simultaneous Delivery of Chemotherapeutic and Thermal-Optical Agents to Cancer Cells by a Polymeric (PLGA) Nanocarrier: an in Vitro Study. Pharm. Res. 2010; 27:2242-2253. [PubMed: 20694526]

62. Huang IP, Sun SP, Cheng SH, Lee CH, Wu CY, Yang CS, Lo LW, Lai YK. Enhanced Chemotherapy of Cancer Using pH-Sensitive Mesoporous Silica Nanoparticles to Antagonize P- 
Glycoprotein-Mediated Drug Resistance. Mol. Cancer Ther. 2011; 10:761-769. [PubMed: 21411714]

63. Bidwell GL 3rd, Davis AN, Fokt I, Priebe W, Raucher D. A Thermally Targeted Elastin-Like Polypeptide-Doxorubicin Conjugate Overcomes Drug Resistance. Invest New Drugs. 2007; 25:313-326. [PubMed: 17483874]

64. El-Sayed IH, Huang X, El-Sayed MA. Surface Plasmon Resonance Scattering and Absorption of Anti-EGFR Antibody Conjugated Gold Nanoparticles in Cancer Diagnostics: Applications in Oral Cancer. Nano Lett. 2005; 5:829-834. [PubMed: 15884879]

65. Medley CD, Smith JE, Tang Z, Wu Y, Bamrungsap S, Tan W. Gold Nanoparticle-Based Colorimetric Assay for the Direct Detection of Cancerous Cells. Anal. Chem. 2008; 80:10671072. [PubMed: 18198894]

66. Frens G. Controlled Nucleation for Regulation of Particle-Size in Monodisperse Gold Suspensions. Nature-Physical Science. 1973; 241:20-22.

67. Deutsch HM, Glinski JA, Hernandez M, Haugwitz RD, Narayanan VL, Suffness M, Zalkow LH. Synthesis of Congeners and Prodrugs. 3. Water-Soluble Prodrugs of Taxol with Potent Antitumor Activity. J. Med. Chem. 1989; 32:788-792. [PubMed: 2564894] 
A
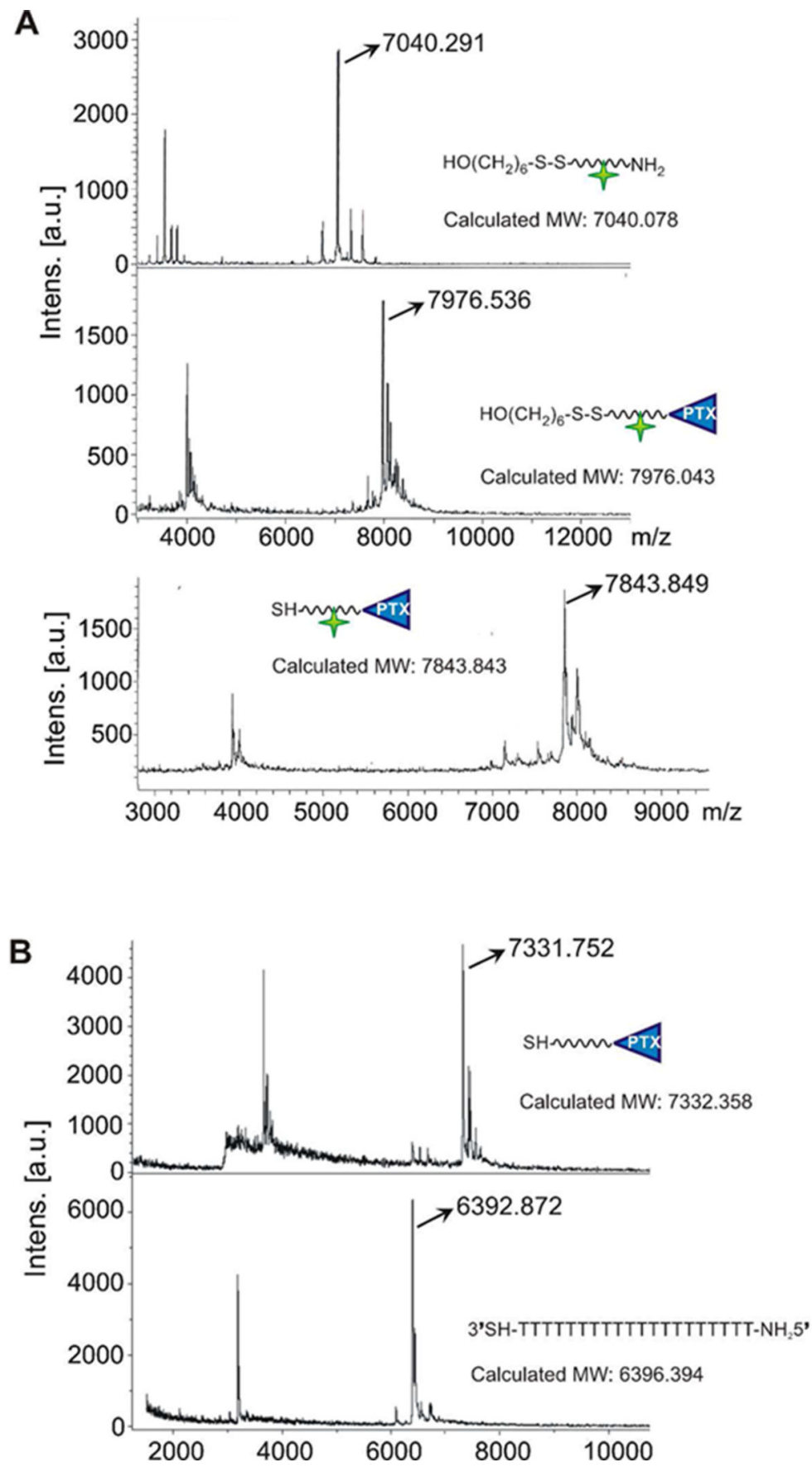

Figure 1.

Characterization of Fluorescein-labeled PTX-DNA (A) and PTX-DNA 2 (B) by MALDIMS. 

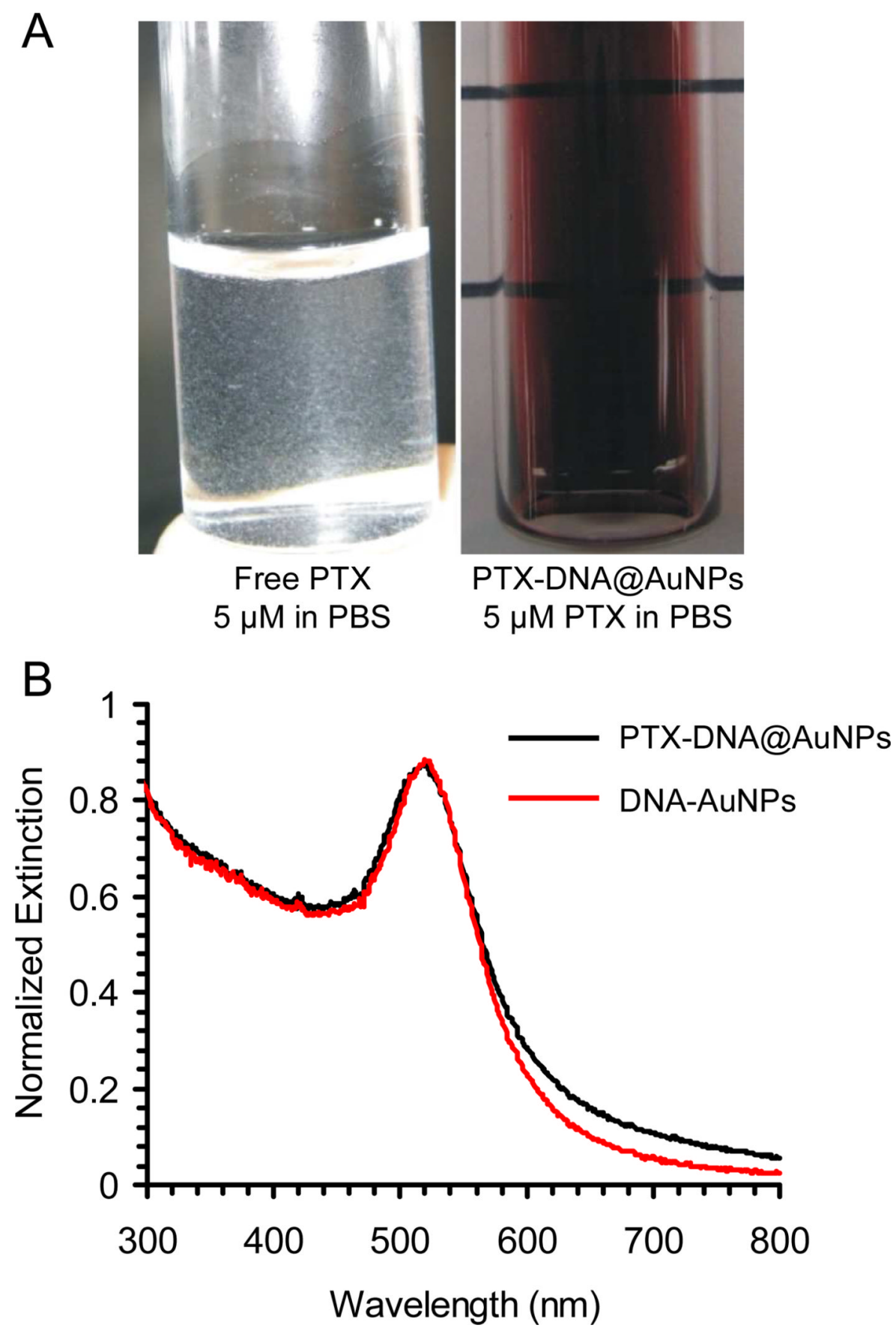

Figure 2.

(A) Digital pictures of PTX-DNA@AuNPs 3 and free Paclitaxel after suspension in PBS buffer and overnight storage; (B) UV-Vis spectroscopy of the PTX-DNA@AuNPs 3 and DNA-AuNPs. 


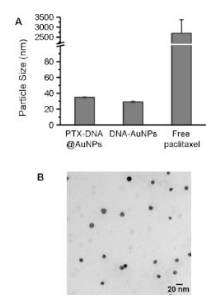

Figure 3.

(A) Hydrodynamic sizes of PTX-DNA@AuNPs 3, DNA-AuNPs and Paclitaxel in PBS buffer $(n=3)$. The compounds were suspended in PBS buffer at the equivalent Paclitaxel concentration of $21.3 \mathrm{ug} / \mathrm{mL}(25 \mu \mathrm{M})$ for dynamic light scattering (DLS) measurement; (B) TEM image of PTX-DNA@AuNPs 3. Scale bar is $20 \mathrm{~nm}$. 


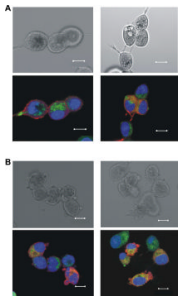

Figure 4.

Bright-field (Upper) and overlaid fluorescent (Lower) images of MCF7 (A) and MES-SA/ Dx5 (B) cells after incubation with $25 \mathrm{nM}$ of Fluorescein-PTX-DNA@AuNPs (Ex./Em. 494/521nm, green) for 6 h. Cellular Lights ${ }^{\mathrm{TM}}$ Actin-RFP (Ex./Em. 555/584nm, red, Invitrogen) was used for cytoplasmic actin staining, and DRAQ5 (Ex./Em 646/681nm, blue, Biostatus Ltd.) for nuclear staining. Scale bar is $10 \mu \mathrm{m}$. 

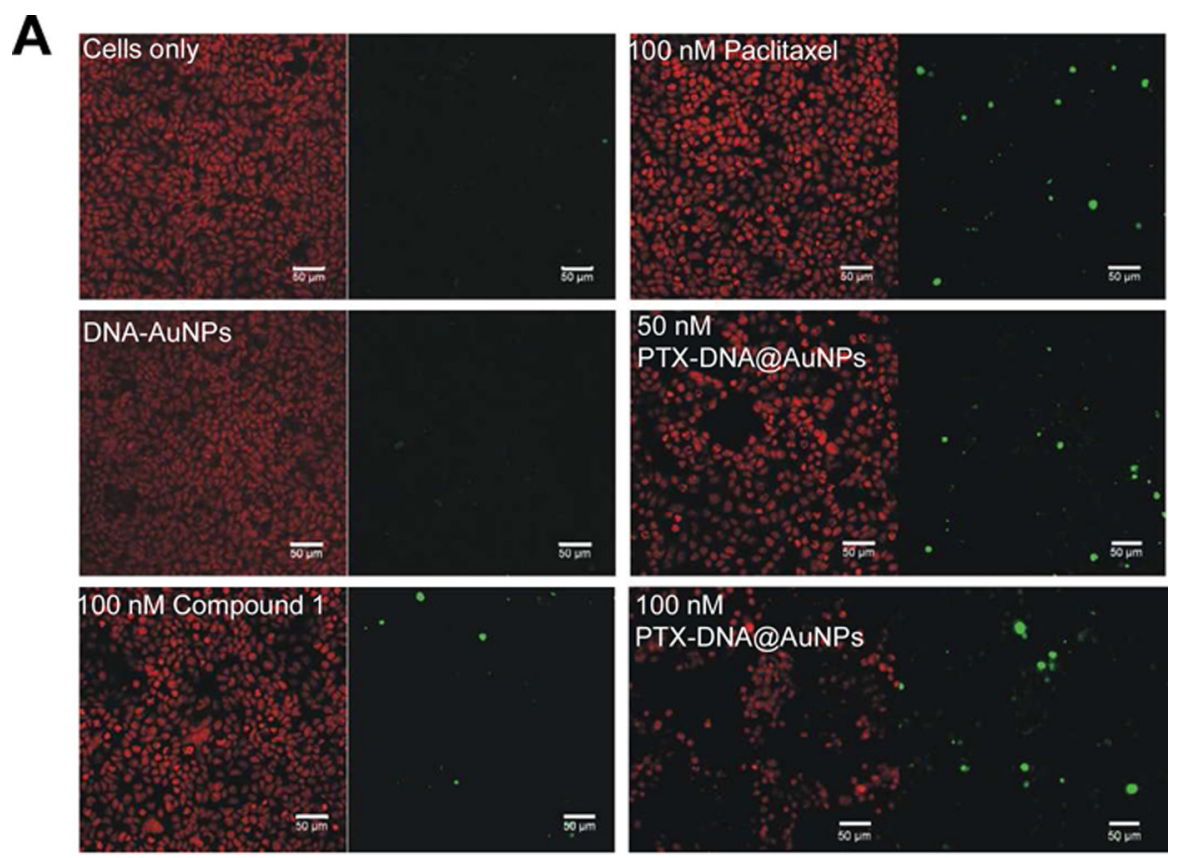

B
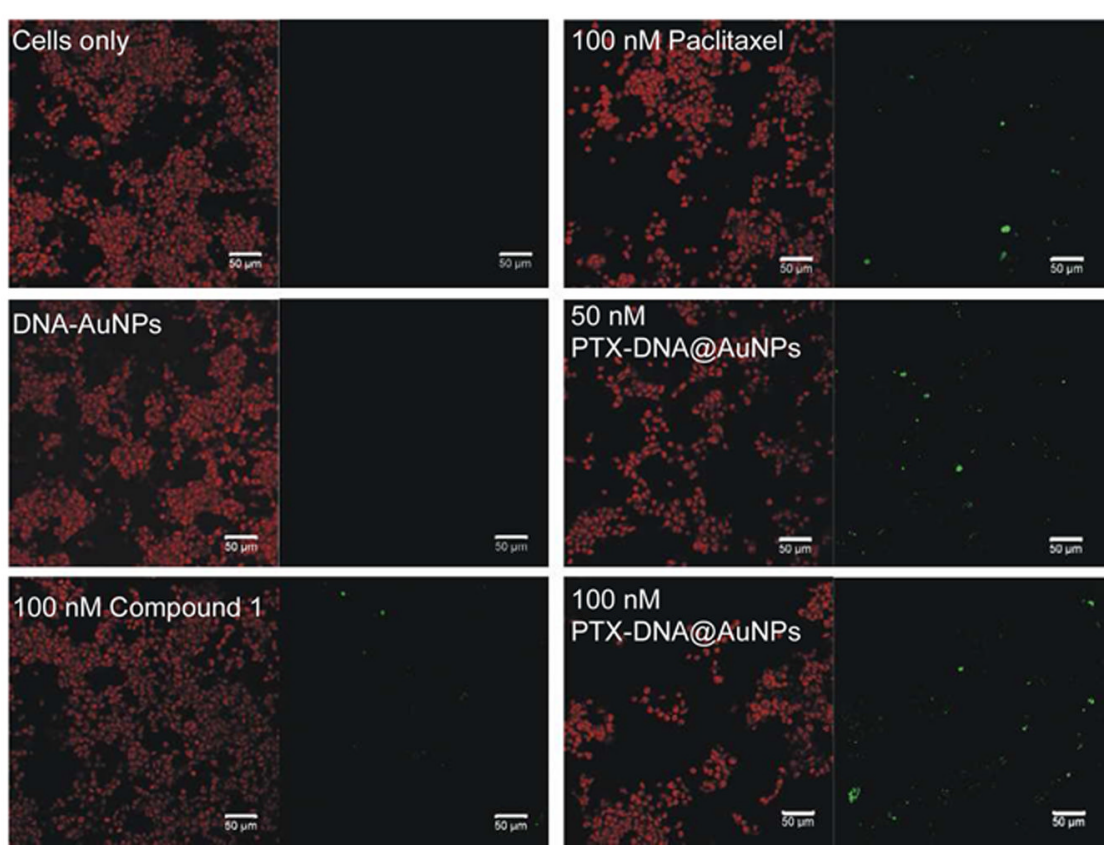

Figure 5.

TUNEL assay testing activity of PTX-DNA@ AuNPs 3 in MCF7 (A) and MES-SA/Dx5 (B) cells. TUNEL (green) and counter-stain (red) images of cells left untreated, DNA-AuNPs, $100 \mathrm{nM}$ of free Paclitaxel and compound 1, and PTX-DNA@AuNPs 3 at the equivalent Paclitaxel concentrations of $50 \mathrm{nM}$ and $100 \mathrm{nM}$. Scale bars are $50 \mu \mathrm{m}$. After treatment by PTX-DNA@AuNPs 3 for 48 h, significant numbers of TUNEL-positive cells and reduced populations are observed in both tested cell lines. 

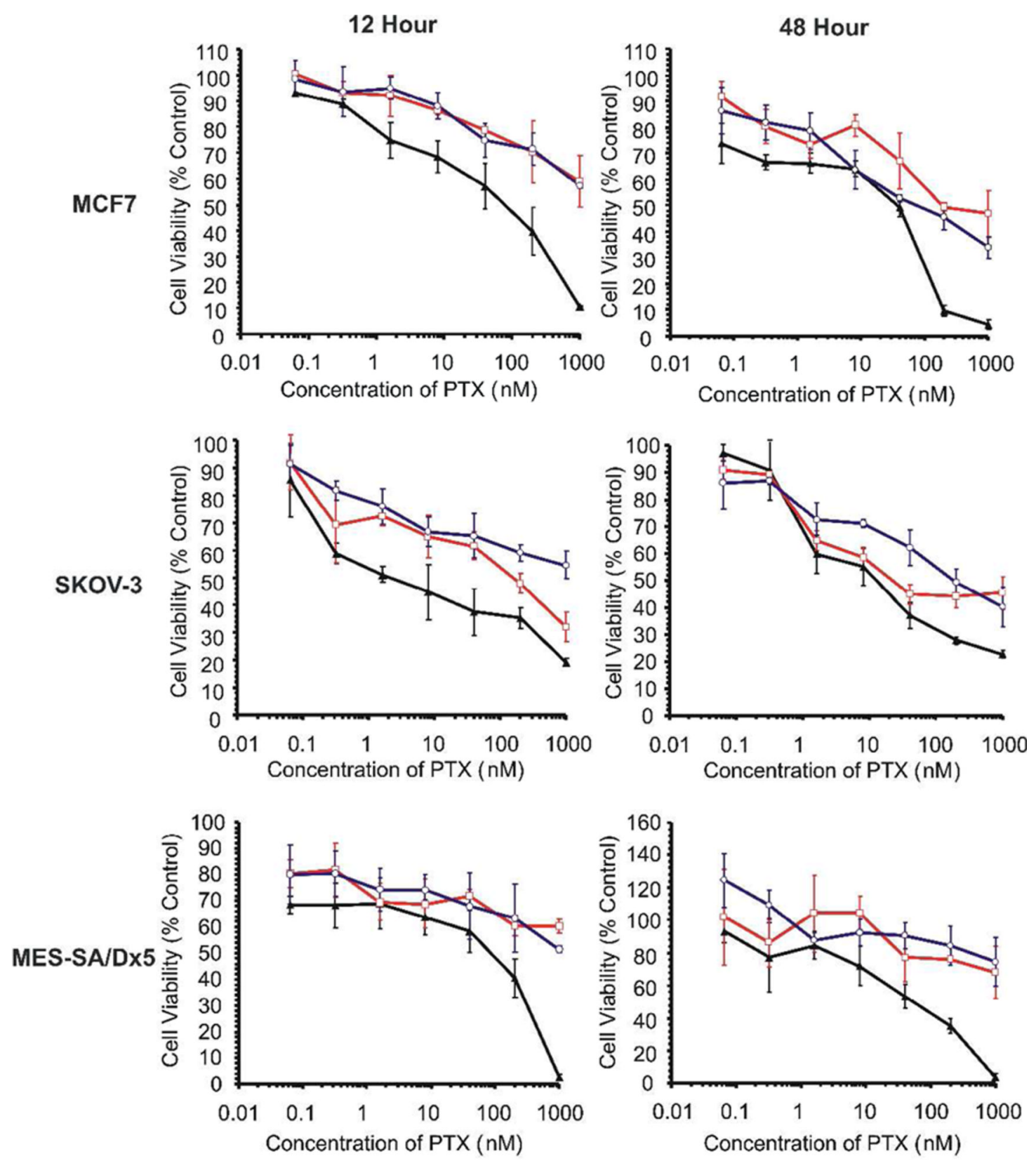

-PTX-DNA@AuNPs $\quad=$-Paclitaxel $\quad \infty$ Compound 1

Figure 6.

Cytotoxicity profiles of PTX-DNA@AuNPs 3 (black triangles), Paclitaxel (red squares) and compound 1 (blue circles) at equivalent Paclitaxel dose with MCF7, SKOV-3 and MES-SA/ Dx 5 cells are present in the top, middle and bottom panels respectively $(\mathrm{n}=6)$. 

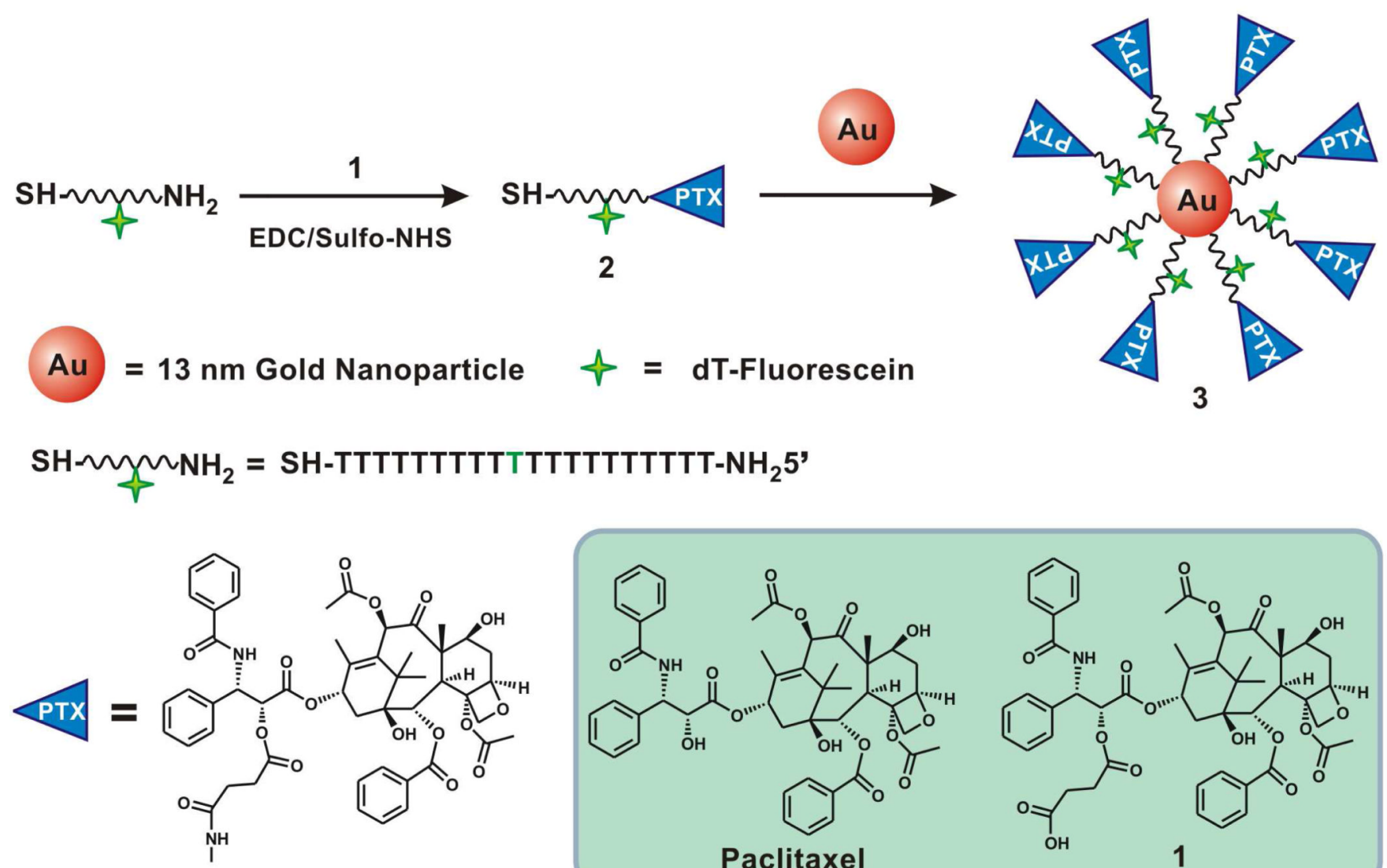

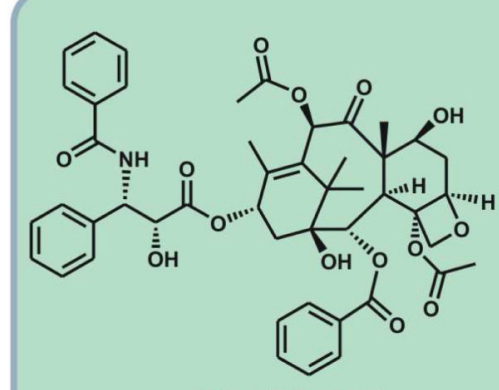

Paclitaxel

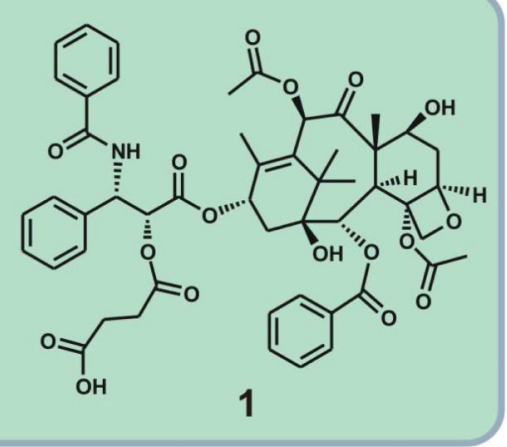

Scheme 1.

Synthesis of PTX-DNA@AuNP conjugates. 


\section{Table 1}

IC $_{50}$ of PTX-DNA@AuNPs 3, Paclitaxel and compound 1 after 12 and 48 h incubation in MCF7, SKOV-3 and MES-SA/Dx5 cells.

\begin{tabular}{|c|c|c|c|c|}
\hline \multirow{2}{*}{} & \multirow{2}{*}{ Incubation time (h) } & \multicolumn{3}{|c|}{ IC $_{\text {50 }}$ (nM Paclitaxel) } \\
\cline { 3 - 5 } & & $\begin{array}{l}\text { PTX-DNA } \\
\text { @ AuNPs 3 }\end{array}$ & Paclitaxel & Compound1 \\
\hline \multirow{2}{*}{ MCF7 } & 12 & 119.4 & $>1000$ & $>1000$ \\
\cline { 2 - 5 } & 48 & 52.6 & 193.0 & 133.2 \\
\hline \multirow{2}{*}{ SKOV-3 } & 12 & 4.3 & 175.6 & $>1000$ \\
\cline { 2 - 5 } & 48 & 17.5 & 28.9 & 188.0 \\
\hline \multirow{2}{*}{ MES-SA/Dx5 } & 12 & 118.0 & $>1000$ & $>1000$ \\
\cline { 2 - 5 } & 48 & 104.5 & $>1000$ & $>1000$ \\
\hline
\end{tabular}

